\title{
Digitization as an ethical challenge
}

\author{
Rafael Capurro'
}

Published online: 1 December 2016

(C) Springer-Verlag London 2016

\section{Digitization is changing all aspects of human life. What is its impact on our understanding of ethics as it has evolved over centuries? Is there something like a Digital Ethics?}

The changes brought about by digitization can be compared with the ones that took place in Europe in Modernity with a peak in the industrial revolution in the 19th century. These changes concerned European self-understanding particularly with regard to the idea that not god but the human being was the center of reality. To be human means not to be god's creature but an autonomous being who understands himself-it was mostly himself and not herself-as a subject facing objects in the so-called outside world. This subject/object dichotomy as developed by, for instance, René Descartes was the basis of the triumphal progress of modern science and technology. Modernity brought also up the paradox of decentering the human subject with regard to the universe (Copernican revolution), natural evolution (Darwin) and even to our own consciousness (Freud) while at the same time providing the basis for the conquest and exploitation of nature as well as for the domination of other nations politically, economically and culturally.

European Modernity, now spread over the world, is Janus-faced: It has brought positive changes in human life while at the same time these changes were and are concomitant with colonialism, imperialism, capitalism, slavery, fascism, world wars and climate change. The self-

Rafael Capurro

rafael@capurro.de

1 International Center for Information Ethics (ICIE), c/o Redtenbacherstr. 9, 76133 Karlsruhe, Germany understanding of humans as autonomous beings implied a change in the moral ideas and ideals based on metaphysical and theological presuppositions inherited from Antiquity and Middle Ages as well as the reasons and procedures for their political legitimization. How is morality without religion possible? How can political power be justified if there is no king by the grace of god? What are the rules of legitimization and the limits of human action if there are no dogmatic prescriptions? Based on which procedures and by which institutions are legal rules to be justified, evaluated and implemented?

Digitization has breathtakingly evolved in the last twenty years implies no less a change in our self-understanding. But who is meant when we speak about "our" self-understanding? We are subjects embedded in a global network of networked objects. Being human means beingin-the-networked-world, most but not all of the time. The modern subject-object dichotomy as well as the dualism of autonomy versus heteronomy has changed. Networked things are not the same as the objects in the outside world imagined by Modernity, nor humans can be conceived of as purely as autonomous beings, something that was already questioned by the modern scientific and technological discoveries themselves. What makes the digital era unique is probably that although digitization is a project of Modernity it does not rely on the subject-object dichotomy in its original absolute form alone. Digitization changes the anthropological self-understanding of encapsulated worldless subjects facing objects in the so-called outside world.

Digital ethics undertakes a critical reflection about ourselves in a world shaped by digital technology. It was developed since the 1940s by pioneers like Norbert Wiener (1894-1964) and Joseph Weizenbaum (1923-2008). It was first called computer ethics and dealt mainly with professional issues of computer scientists although Wiener and 
Weizenbaum were well aware that the ethical issues about the impact of computer technology concerned society as a whole and not just a profession (Bynum 2015). This became particularly clear when the concept of information society became popular in the 1980s. In 1997 UNESCO held the first International Congress on Ethical, Legal and Societal Aspects of Digital Information (INFOethics). ITU (International Telecommunication Union) took care of the World Summit on the Information Society (WSIS) held 2003 in Geneva and 2005 in Tunisia. During the last fifteen years, professional societies dealing with ethical issues of IT were created such as INSEIT (International Society for Ethics and IT) or the International Center for Information Ethics (ICIE). Journals, academic courses, congresses and workshops flourished soon. The website of ICIE provides comprehensive information on publications, events and courses in the field.

The label Digital Ethics is recent. The Academy of Korean Studies in Seoul invited me to speak on this topic at the 2009 Global Forum on Civilization and Peace (Capurro 2010). The Center for Digital Ethics and Policy at the Loyola University Chicago published the proceedings of its first conference: "Digital Ethics. Research \& Practice" in 2012. The Stuttgart Media University created in 2014 an Institute for Digital Ethics. In the meantime, ethical issues dealing with the impact of digitization on society are daily topic of newspapers and journals worldwide. This public debate mirrors the moral and legal changes in society. New customs (Latin: mores) arise. We should distinguish moral customs from the academic discipline dealing with them, namely ethics or moral philosophy.

According to the French philosopher Michel Foucault, ethics means the problematization of morality (Foucault 1983). Digital Ethics is a special field of Information Ethics that embraces ethical issues of information and communication beyond the ones raised by digitalization. Digital Ethics is closely related to, for instance, Bioethics, Medical Ethics and Business Ethics.

\section{Per definition ethics should help humans in their moral decisions. How far does this work in a rapidly changing and complex digital world?}

The kind of help ethical theories can provide is one of the analyzing and criticizing theoretical presuppositions as well possibilities of action and their potential consequences for the actors and the world in which they live. The plethora of ethical theories in different cultures and epochs is witness of the complexity of the issues dealing with human action. They concern not just the responsibility of encapsulated worldless subjects as envisaged by the modern subject-object dichotomy, but their original social embeddedness sharing a common world. Ethical analyses aim at questioning theoretical and practical biases such as prima facie clear concepts and goals, hidden agendas, power structures and information myths as well as fostering intercultural dialog on basic human experiences and values. It is not the aim of ethics to take away responsibility about the risks that any theoretical or practical option implies for ourselves, for others and for the world we share with others. This is particularly relevant in case the existential coordinates that rule human life are subject to change in such a way that they cannot provide any more the kind of protection a symbolic "immune system" (Sloterdijk 2009) that morality and legal systems should provide.

We do not live in two separate worlds, namely the analog and the digital one. But it is no less true that beingin-the-networked-world has become a predominant feature of today's society. Moreover, sharing a common world implies in the meantime that not only humans but other living beings as well as natural and artificial things are more and more connected to the Internet. This creates dysfunctionalities, collapses and breakdowns. Symbolic systems that were designed to protect individuals and societies turn out to be insufficient or outdated. New questions arise about the criteria of good life. Digitization becomes symptomatic for societal transformation. This is the reason why research in information ethics is so crucial today. But thinking needs time.

\section{We post and tweet all the time. Is this kind of using social networks and online platforms a symptom of the human need for recognition?}

Yes, but not only. I believe that the possibilities created by social networks and online platforms give rise to narcissism, exhibitionism and voyeurism but also to new possibilities of presenting oneself authentically. I have analyzed this issue in the context of an interdisciplinary symposium on AIDS organized in 2008 by the Department of Protestant Theology of the Goethe University Frankfurt (Capurro 2009). I dealt with the question whether there are ethical limits of the mediatization of human suffering. I analyzed the difference between being exposed to suffering by others in the mass media versus being exposed by oneself in the Internet. But this difference has become problematic due to media convergence. The reality of social media and online platforms is complex not only with regard to the uses and misuses of personal data but also because of different moral and legal norms and their cultural frameworks (Capurro 2013).

The ambiguity seems to arise also from the derivative new ethical imperative: "Communicate all the time everything to everybody!" This imperative remains effective also when the user believes that the service provider 
will take care of her privacy which is not the case as we know since Edward Snowden. Total communication takes us, paradoxically, to being "alone together" (Turkle 2011). Human freedom means the freedom to conceal or reveal who we are. An imperative of total un-concealment is no less un-human that another of total concealment. The difference between living in online networks on the one hand, and in physical or analog environments on the other hand can be misleading in case the former, which has been called onlife (The European Commission 2015) and the latter, offlife are understood and/or experienced as living in two separate worlds instead of their being viewed as two different ways of being-in-the-world (Capurro 2013a).

\section{Is it possible that the ongoing process of digital networks connecting humans via smart phones as well as machine-machine communication, particularly in the case of industrial production, resembles Pandora's box?}

Everything I produce is a part of me but it has also an own way of being. I can conceal and reveal myself in my works. What I produce can be exchanged. Exchange value and use value, pace Karl Marx, need to be reconsidered today. A view of the human self as a bunch of digital data becoming an object of economic transactions is not per se wrong if humans are not considered to be a mere bunch of digital data. This is a Kantian argument that legitimizes processes of mutual recognition and valuation in the digital era (Eldred 2013). Hannah Arendt's analysis of the "human condition" under the perspectives of labor, work and action (Arendt 1998) is based, according to the Australian philosopher Michael Eldred, on a misconception of the concept of value as grounded on objectivity and durability while in fact value is "a social relation of mutual estimation of performed labor in value-things (commodities, money)" (Eldred 2013a, 97). Digitization accelerates the movement of the reified value, as well as of the whole production and delivery process of goods, the knowledge on how to produce them, the marketing and the reputation of the people and organizations involved. The social interplay between producers and consumers or users takes place today in online platforms that offer at the same time the possibility for users and customers to actively promote themselves as a prosumer. Digital marketing becomes also a way of defining "who am I?" or "who are we?" in a reified interplay. This interplay can be authentic or inauthentic, with a lot of possibilities in between, depending, for instance, on how others profit by reification through misuse, extortion, defamation, oppression and even annihilation. These and other negative forms of social interplay are not originally different from the ones in the offline world, but the digital medium offers other possibilities of being-with-others as well as of machine-machine interactions that come out of Pandora's digital box. We, her children, being at the same time the "fore-thinker" Prometheus and the "after-thinker" Epimetheus, must be aware in advance and take care of future risks and responsibilities for our life and the life of others with whom we share the common world.

\section{You speak often about a robotization of human beings. Where do you see at present the greatest dangers?}

Robots are becoming widespread in everyday life performing different tasks in health care, hotels, restaurants, schools and private homes. In each case, we have to think about the criteria we use in order to qualify ethically and legally their use for good life. To speak about dangers of robotization might appear as a Western bias. In Buddhist and Shinto cultures, the context of playing and theater together with a non-metaphysical conception of the human self enables a different attitude toward robots as in Western societies, although there is also the Western tradition of marionettes, like the toys of Jacques de Vaucansson (1709-1782) (Capurro 2015a). Robotization might be seen then as a danger for human dignity, a value that is enshrined not only in the German constitution but also in the European Charta of Human Rights and even in the Universal Declaration of Human Rights. In some way, this fear is a symptom about Western anthropocentrism being questioned by digitization.

On a more pragmatic perspective, the present debate about the dangers of robotization takes place around drones (Marsiske et al. 2012) as well as about the issues arising from the massive use of digital devices for surveillance and the question about how far do we want to delegate personal responsibility to algorithms for instance in the case of driverless cars. The ethical debate turns then into a debate about freedom versus security as well as between autonomy versus heteronomy that shows that digitization has its roots in Modernity although it decenters the human subject from its privileged position and makes her aware of the interplay in which it is embedded.

\section{Knowledge is a key value in today's working environment. Can we foresee the rise of a new working class?}

One reason why knowledge is a key value in today's working environment is that we do not live in a slave-based economy as in Antiquity or in modern colonial states 
although digital technology fosters new forms of oppression and exploitation. The French Revolution brought about the democratization of libraries owned by nobility and the Catholic Church. With the Internet and the World Wide Web, digital libraries as well as digital encyclopedias like Wikipedia that we should better call endictyopedias (Greek diktyon $=$ network) are set up (Capurro 2004). Since the 1970s with the production of computerized bibliographic databases, the importance of knowledge for public (research) policy was highlighted particularly by, for instance, the Weinberg Report "Science, Government, and Information" (Weinberg 1963). Alvin M. Weinberg (1915-2006) was the chairman of President Eisenhower's (and Kennedy's) Science Advisory Committee.

The use of digital technologies in industry as well as in society at large goes hand in hand with the development of bibliographic und full text databases, search engines, social platforms, mobile technologies, the internet of things and robotics, to mention just a few areas. It is symptomatic for our era that what started as a tool, namely the development of search engines to deal with bibliographic data for scientific research and industry has now become a core of the digital era. As with industrial society, new monopolies and power struggles arise between digital capitalism and the (new) working class. Millions and even billions of users worldwide give their data for free to a few global players and are happy to be addicts of their "free" services at least until they become aware that the digital capital owners use the personal data of their customers without their consent either for profit or under political pressure as disclosed by whistle blowers like Edward Snowden. In other words, class struggles in the 21 st century are also between digital customers and data owners.

We are facing different forms of class divide based on the exclusion from access to digital networks as well as on economic and educational differences within a society as well as between nations. The so-called digital divide is not just a technical but a complex local and global societal phenomenon for which key ethical questions concerning justice, freedom, peace, cooperation and identity have to be redefined. Modern concepts such as autonomy, democracy or the rule of law under the umbrella of the nation state are part of the problem when dealing with global issues such as climate change, digital economy or cybertariats, the digital version of former proletariats (Gopal 2016). A new form of cosmopolitanism is underway that should embrace the well-offs and the cybertariats. Digital technologies might help overcoming social inequalities and forms of exclusion, but they might also aggravate these and other divides in society.

\section{What is most needed in schools and other educational institutions in order that digital natives become aware that digitization is not the only measure for good life?}

Uruguay, the small South American country, started in 2007, as the first country worldwide, an experiment called "Plan Ceibal." "Ceibo" is the name of a native tree as well as an acronym for "Conectividad de Informática Básica para el Aprendizaje en Línea" (Connectivity with Basic Informatics for Online Learning) (Plan Ceibal 2016). According to this plan, the state would provide a laptop for every child going to public schools, following Nicholas Negroponte's idea One Laptop per Child presented at the World Economic Forum in 2005.

This was a good idea but ten years later the situation of public education in Uruguay is dramatic and can be compared, according to Jorge Grünberg, Rector of the ORT University in Montevideo, with the one in Tanzania (Grünberg 2014). There are social and economic reasons for this. Middle-class children, living in better neighborhood, having access to books and whose parents have university education are in a much better position when they go to school that cannot be equated with technology alone.

What do digital natives need in order not to be dazzled by digitization? A globalized world is a world of translations. The knowledge of foreign languages enables us to take a distance of ourselves taking a distance from our cultural bias. In a broader sense, exercising translation can be learned from the history of science with regard to scientific revolutions as well as from the history of technology. Translations are exercises in creativity which is the engine of social change. They are also an ethical exercises dealing with challenging traditional customs, principles and values, i.e., the ethos that holds together a society. If we give time to the students for different kinds of translations particularly with regard to the difference between onlife and offlife, they will have the opportunity to take a critical view of digitization.

\section{Concerning privacy: What are the consequences in case companies, employers and friends want to know everything about us? Is this a danger for our freedom? What is the drawback of too much surveillance?}

Privacy is neither a relict of bourgeois society as Marxists believe, nor is it a hopeless struggle against digital windmills in a restless information society as digital evangelists propagate. Thinking about the relation between the realm 
of the public and the private is no more and no less than thinking about freedom as the capacity to reveal and conceal who we are. The public-private relation has had different shapes in other epochs and societies (Capurro 2013 b, 2015b). The idea that we could become completely transparent to ourselves as individuals or as society or that others could know everything about us or we about them is a myth. The question is about the reasons and the legitimization for such need. If I reveal something about myself in a specific context, this does not mean that I automatically agree that such data can be widespread to other contexts without my consent. This is the issue raised by Helen Nissenbaum in her influential book "Privacy in context. Technology, Policy and the Integrity of Social Life" (Nissenbaum 2010). Privacy means then that the information flow does not continue only on the basis of customs and convention but also due to "key organizing principles of social life, including moral and political ones." (Nissenbaum 2010, 231) In a recent book by Finn Brunton and Helen Nissenbaum: "Obfuscation. A User's Guide for Privacy and Protest" (Brunton and Nissenbaum 2015) the authors show which kinds of mechanism of obfuscation users can learn in order to protect themselves. This is a kind of guerrilla tactics to which I point ironically with the maxim "Never enter your real data" (Capurro 2011). Whistle blowers are needed more than ever but also rules of fair play at national and international level. And we need institutions and forms of political debate dealing with ethical and legal issues of the information society (Capurro 2015b).

\section{Germany appears often, compared with the USA, as being obsessed with the dangers of digitization. Do we put a spoke in our wheel economically when we praise data protection?}

We should not worry about that and pose, instead, to those who laugh at us, the opposite question whether they want a thoughtless society where living under a liberal government with a search for happiness protecting constitution they should care about global rules of fair play for the digital society together with all nations. Questionable is this issue also because the mockery might be just blindness about regarding the conflict between freedom and data protection by simply believing that freedom is the higher value. In fact, what is the higher value is the commercial interest of some global players that fear less revenue in case of state regulation. Freedom means in this case, "let us make the rules according to what our customers want. They should decide what is good or bad for them." On the opposite side is overregulation by a nanny state. And what is most remarkable is that in some cases, liberal states turn into nanny states and vice versa. Lawrence Lessig, Helen Nissenbaum and Evgeny Morozov, to mention just a few, have done a thorough analysis of this issue, beyond the clichés on both sides of the Atlantic as well in a global scale.

\section{Automobile manufacturers worldwide are working hard developing driverless cars. This means a further development of digital networks as well as a new source of ethical issues. Who should have the responsibility that such a discourse gets started?}

Driverless cars are a symptom that something is going wrong locally and globally with our transportation system. It is not only the chaos in our roads and streets, particularly in megacities like New Delhi or Sao Paulo, but also the impact on climate change that raises the question about which kind of transportation is adequate in the 21 st century from the perspective of digitization. This is not only a technological but also an ethical and legal challenge. Norms and rules do not fall from heaven but are embedded in legal systems, cultural traditions and geographic conditions. It is possible to program traffic rules into a driverless car, but this does not mean that the car mutates into a being capable of reflecting critically, i.e., ethically on such rules taking action in a given situation. A code of morality or a legal code is not identical with moral philosophy or jurisprudence. When a driverless car follows a rule, this does not mean that the car is able to give reasons about its decision beyond the fact that such reason were given to it. It is not able to interpret the norms.

This is the reason why the use of the term autonomy with regard to driverless cars is problematic. Autonomy is a key term of moral philosophy particularly since Modernity. A driverless car is basically a heteronomous agent not only because it is not able to move by itself like a living being, although it is called "auto-mobile," but also because it is not able to give itself the norms according to which it should act and to take the responsibility for what it does or does not in a given situation. If something goes wrong, then manufacturers, programmers and buyers have to face the issue at stake at least as long as cars or other "autonomous" things do not mutate into philosophers with whom we could continue the talk we are having right now. It would be silly to do business as in a historic situation in which we face what we could call, following Thomas S. Kuhn's concept of "scientific revolution," a technical revolution (Kuhn 2012). In this case, we are not facing the challenge of understanding an aporetic situation as a motivation for thinking and acting beyond a traditional way of thinking or producing. For a philosopher like Socrates, a productive dialog ends with an aporia that is 
supposed to wake up the reason and imagination to go beyond, in case one is able to accept that the way done so far does not take her further.

There are a lot of excellent managers and engineers in the automobile industry that are able to face the challenge of digitization also as an ethical challenge, i.e., as a challenge that gives rise to radical solutions beyond the narrow interests of profit making.

\section{Some companies understand globalization and digitization as a strategic goal. What risks does this imply in case the local context becomes less and less relevant?}

In his book "What is Globalization?" the German sociologist Ulrich Beck (1944-2015) uses the term "globalization" coined by the sociologist Roland Robertson (Beck 1997). The risks of globalization come from the trap of globalism. Cultural diversity must be taken into account if manufacturers expect that people like their products and are ready to pay for them. The more a company becomes global, the more it must pay attention to locality. But this strategy can turn into a new kind of cultural and economic colonialism. Local users must be aware of this (Capurro 2013). We should get rid of the ambitions and obsessions associated with digitization. This does not mean that we should demonize it. Socratic virtues like self-mastery (enkrateia) and self-restraint (autarkeia) are important but we, in the West, should learn from the Buddhist practices of release, selflessness and communion with other living and non-living beings in order to imagine a world beyond the aporias of Modernity.

Curmudgeon Corner Curmudgeon Corner is a short opinionated column on trends in technology, arts, science and society, commenting on issues of concern to the research community and wider society. Whilst the drive for super-human intelligence promotes potential benefits to wider society, it also raises deep concerns of existential risk, thereby highlighting the need for an ongoing conversation between technology and society. At the core of Curmudgeon concern is the question: What is it to be human in the age of the AI machine? -Editor.

Acknowledgements This article is an English translation of the extended version of an interview for the German journal business impact. The questions were posed by the editors of the journal Hilmar Dunker and Ralf Bretting. The short version of the interview was published in (Capurro 2015). I thank Joseph Brenner (Switzerland) and Jared Bielby (Canada) for critical comments as well as for polishing my English.

\section{References}

Arendt H (1998) The Human Condition. The University of Chicago Press, Chicago
Beck U (1997) Was ist Globalisierung? Irrtümer des GlobalismusAntworten auf Globalisierung. Frankfurt am Main (Engl. transl. What is Globalization, Cambridge 1999)

Brunton F, Nissenbaum H (2015) Obfuscation. A user's guide for privacy and protest. MIT Press, Cambridge

Bynum T (2015) Computer and information ethics. In: Zalta EN (ed) The Stanford Encyclopedia of Philosophy (Winter 2015 Edition), http://plato.stanford.edu/archives/win2015/entries/ethicscomputer/

Capurro R (2004) Skeptical knowledge management. In: Hobohm $\mathrm{H}-\mathrm{C}$ (ed) Knowledge management. Libraries and librarians taking up the challenge. IFLA Publication 108, Munich, pp 47-57. http://www.capurro.de/skepsis.html

Capurro R (2009) Fremddarstellung-Selbstdarstellung. In: Alkier S, Dronsch K (ed) HIV/Aids. Ethische Perspektiven. Berlin, pp 143-156. http://www.capurro.de/aids.html

Capurro R (2010) Digital ethics. In: The Academy of Korean Studies (ed): 2009 Civilization and peace, Korea: The Academy of Korean Studies 2010, pp 203-214. http://www.capurro.de/korea. html

Capurro R (2011) Never enter your real data. http://www.capurro.de/ realdata.html

Capurro R (2013) Ethical issues of online social networks in Africa. In: Innovation. Journal of appropriate librarianship and information work in Southern Africa, vol 46, December, pp 161-175. http://www.capurro.de/OSNAfrica2012.html

Capurro R (2013a) Medicine 2.0. Reflections on a pathology of the information society. In: Innovation, journal of appropriate librarianship and information work in Southern Africa, N. vol 46, June pp 75-96. http://www.capurro.de/Medicine2_0.html

Capurro R (2013b) Intercultural aspects of digitally mediated whoness, privacy and freedom. In: Capurro R, Eldred E, Nagel D (eds) Digital whoness. Identity, privacy and freedom in the cyberworld. Walter de Gruyter, Frankfurt am Main, pp 211-234

Capurro R (2015) Digitale Ethik. In: Business impact, 04/2015, pp 40-43. http://www.capurro.de/businessimpact2015.pdf

Capurro R (2015a) Living with online robots. http://www.capurro.de/ onlinerobots.html

Capurro R (2015b) Shapes of freedom in the digital age. In: Keseroğlu HS, Demir G, Bitri E, Güneş A (eds): 1st international symposium on philosophy of library and information science. Ethics: theory and practice. Istanbul, pp 1-13. http://www. capurro.de/kastamonu.html

Eldred M (2013) Guest editor: Reputation in the cyberworld. IRIE issue 19. http://www.i-r-i-e.net/issue19.htm

Eldred M (2013a) Arendt on whoness in the world. In: Capurro R, Eldred M, Nagel D (eds) Digital whoness. Identity, privacy and freedom in the cyberworld. Frankfurt am Main, pp 79-98

Foucault M (1983) Discourse and truth: the problematization of parrhesia. University of California at Berkeley, OctoberNovember 1983. http://foucault.info/documents/parrhesia

Gopal TV, Duggal P, Lobo A, Guest Editors (2016) Ethics for Indian cybertarians. International review of information ethics (IRIE), 26 (in prep.) http://www.i-r-i-e.net/call_for_papers_26.htm

Grünberg J (2014) Uruguay es comparable en educación con Tanzanía. In: Latinoamérica. Revista de Prensa, 17.09.2014 http://www.lacelosia.com/uruguay-es-comparable-en-educacioncon-tanzania-segun-el-rector-jorge-grunberg/

Kuhn TS (2012) The structure of scientific revolutions, 4th edn. University of Chicago Press, Chicago

Marsiske H-A (ed) (2012) Kriegsmaschinen-Roboter im Militäreinsatz. Heise, Hannover

Plan Ceibal (2016) A Uruguayan initiative to introduce Information and Communication Technologies (ICT) in primaryand secondary public education 
Sloterdijk P (2009) Du musst dein Leben ändern. Über Anthropotechnik, Frankfurt am Main, Suhrkamp

The European Commission (2015) Digital agenda for Europe. A Europe 2020 initiative. The onlife manifesto. Being human in a hyperconnected era. https://ec.europa.eu/digital-singlemarket/sites/digital-agenda/files/Manifesto.pdf

Turkle S (2011) Alone together: why we expect more from technology and less from each other. Basic Books, New York
Weinberg AM (1963) Science, government, and information. The responsibilities of the technical community and the government in the transfer of information. Washington D.C.: The White House, January 10, 1063. http://garfield.library.upenn.edu/ papers/weinbergreport1963.pdf 